\title{
Literasi Media Digital untuk Pendampingan Anak bagi Ibu-Ibu Dusun Jodog Desa Gilangharjo Kecamatan Pandak Kabupaten Bantul
}

\author{
Yuli Setyowati \\ Sekolah Tinggi Pembangunan Masyarakat Desa "APMD" Yogyakarta \\ gracedista72@gmail.com
}

\begin{abstract}
Abstrak
Media digital banyak diakses masyarakat namun mereka tidak mampu memanfaatkan media tersebut secara cerdas. Literasi media digital terutama bagi ibu-ibu perlu dilakukan agar terjadi peningkatan kemampuan mengakses media digital agar mereka dapat melakukan pendampingan kepada anak-anaknya. Tujuan kegiatan pengabdian kepada masyarakat ini meliputi: 1) memberikan edukasi dan sosialisasi pada para ibu-ibu tentang karakteristik media digital yang diakses oleh anak-anak, 2) memberikan pengetahuan tentang dampak penggunaan media digital dalam perilaku dan perkembangan psikologis anak-anak, 3) memberikan dorongan kepada ibu-ibu untuk mampu melakukan pendampingan kepada anak-anak dalam mengatur penggunaan media digital secara cerdas. Metode yang digunakan dengan memberdayakan masyarakat melalui sosialisasi, diskusi dan pendampingan. Sasaran kegiatan ini adalah ibu-ibu Dusun Jodog Desa Gilangharjo Kecamatan Pandak Kabupaten Bantul. Program dilaksanakan pada bulan Agustus dan September 2020. Hasil dari kegiatan ini adalah: 1) ibu-ibu semakin paham tentang karakteristik media digital, 2) ibu-ibu semakin paham tentang dampak penggunaan media digital dalam perilaku dan perkembangan psikologis anakanak, 3) ibu-ibu semakin efektif melakukan pendampingan kepada anak-anak dalam mengatur penggunaan media digital secara cerdas.
\end{abstract}

Kata kunci: literasi, media, digital, pendampingan

\section{Pendahuluan}

Revolusi industri 4.0 atau sering disebut revolusi media digital mendorong bangsa Indonesia untuk beradaptasi dengan berbagi macam perkembangan teknologi dan kontennya. Seperti yang disampaikan oleh Presiden Joko Widodo pada Sidang Tahunan MPR 2018 lalu, yang mendorong Indonesia beradaptasi memasuki revolusi industri 4.0. Tentunya negara bukan hanya mempersiapkan prasarana dan sarana saja tetapi yang lebih penting adalah menyiapkan kecakapan dan kemampuan pengguna media digital tersebut. Untuk itu, pemerintah sudah seharusnya melakukan langkah-langkah yang serius dalam menguatkan literasi digital pada masyarakat.

Data pengguna internet di Indonesia sat ini mengalami peningkatan setiap tahunnya. Data terbaru yang dirilis pada bulan Februari 2020 dari laporan We Are Sosial ada sejumlah 175,4 juta penduduk Indonesia yang mengakses internet dan hal ini mengalami kenaikan 
sebesar $17 \%$ atau 25 juta pengguna dari tahun sebel;umnya (https://inet.detik.com/cyberlife/d4907674/riset-ada-1752-juta-pengguna-internet-di-indonesia). Berdasarkan data tersebut maka ada sekitar 64\% dari jumlah penduduk Indonesia sebesar 272,1 jiwa mengakses media digital. Rata-rata persentase pengguna mengakses internet melalui handphone dan smartphone. Dari data tersebut, pengguna internet laki-laki lebih tinggi dibandingkan pengguna perempuan, walaupun data pengguna perempuan juga mengalami peningkatan setiap tahunnya. Fenomena yang menarik dari data tersebut menunjukkan bahwa mayoritas pengguna internet perempuan aktif di media sosial dan digunakan untuk kegiatan tidak produktif (https://www.suara.com/lifestyle/2019/07/30/).

Di tengah situasi pandemi covid-19 ini, penggunaan media juga perlu mendapat perhatian serius, karena banyak informasi yang mengacaukan dan bersifat hoaks. Oleh sebab itu dengan melihat data tersebut maka literasi media digital terutama bagi ibu-ibu perlu dilakukan dan kegiatan ini harus dilakukan seperti halnya kampanye yang secara rutin diselenggarakan agar terjadi peningkatan kemampuan bagi mereka untuk mengakses media digital. Media digital banyak diakses masyarakat namun mereka tidak mampu memanfaatkan media tersebut supaya lebih bermanfaat.

Kalangan remaja juga banyak mengakses media digital. Remaja usia 15-19 tahun yang menempati posisi teratas dalam penggunaan internet. Ini berarti rata-rata usia remaja selalu mengakses internet setiap harinya. Berdasarkan data dari We Are Sosial penggunaan internet di Indonesia mencapai 8 jam dalam seharinya dan 4 jam digunakan untuk akses media sosial. Bila melihat kondisi ini maka perlu adanya upaya untuk mendorong ibu-ibu agar dapat melakukan pendampingn kepada anak-anaknya dalam menggunakan media digital. Banyak peristiwa buruk yang terjadi pada remaja karena ketidakpahaman mereka dalam menggunakan media digital tersebut. Misalnya adanya kasus perkosaan karena perkenalan remaja melalui FB, atau adanya kasus penyebaran foto mereka yang tergolong pornografi. Peristiwa yang umumnya terjadi adalah kecanduan remaja pada gadget. Kecanduan ini akan menimbulkan banyak permasalahan lain misalnya; habisnya uang saku hanya untuk membeli kuota internet, remaja menjadi malas belajar dan pertemanan hanya dilakukan di dunia maya bahkan terkadang remaja terlalu percaya dengan seseorang yang mereka kenal di dunia maya, hingga dampaknya terhadap kesehatan remaja.

Upaya membudayakan literasi media di kalangan masyarakat pada umumnya, dan kalangan remaja pada khususnya menjadi salah satu concern Program Studi Ilmu Komunikasi STPMD “APMD". Masyarakat sebagai pengguna media diharapkan dapat berdaya ketika harus berhadapan dengan perkembangan media yang sangat gencar dengan berbagai konten yang dapat membawa dampak negatif bagi masyarakat. Upaya ini dipandang paling efektif dimulai dari keluarga. Dalam hal ini ibu-ibu memiliki peran yang sangat besar dalam melakukan pendampingan kepada anak-anaknya. Untuk itu kegiatan pengabdian kepada masyarakat ini sangat penting dilakukan pada masa sekarang.

Perkembangan media digital saat ini banyak menimbulkan dampak negatif, hal itu dikarenakan masyarakat belum memiliki kemampuan literasi yang baik. Anak-anak adalah bagian dari masyarakat yang lahir di saat teknologi komunikasi sudah berkembang pesat, sehingga membutuhkan perhatian berkaitan dengan penggunaan media digital tersebut dengan 


\section{Jcommdev}

JCommdev- JOURNAL OF COMMUNITY DEVELOPMENT \& EMPOWERMENT

cara memperkuat literasi media digital kepada orang tuanya (dikhususkan ibu-ibu) agar ibu-ibu ini dapat melakukan pendampingan yang lebih efektif kepada anak-anaknya.

Penelitian yang dilakukan oleh Dewi Novianti dan Siti Fatonah dengan judul "Literasi Media Digital di Lingkungan Ibu-Ibu Rumah Tangga di Yogyakarta" dalam Jurnal Ilmu Komunikasi, Volume 16, Nomor 1, Januari-April 2018 menunjukkan bahwa sebagian besar ibuibu rumah tangga di Desa Babadan, Banguntapan, Bantul belum mengenal cara menggunakan media digital cerdas. Mereka sudah biasa menggunakan gadget atau smartphone. Mereka aktif di dasa wisma atau PKK serta aktivitas desa lainnya di lingkungannya. Setelah diadakan FGD, sosialisasi serta pelatihan literasi media digital, ibu-ibu ini menjadi agen-agen perubahan literasi media digital. Ibu-ibu rumah tangga tersebut menyosialisasikan dan mendiseminasikan literasi media digital baik di lingkungan keluarganya, maupun di lembaga-lembaga atau organisasiorganisasi di mana mereka menjadi pengurus atau anggota di dalamnya. Mereka berhasil mengajak lingkungannya untuk cerdas mengonsumsi media, khususnya media digital. Desa Babadan di mana ibu-ibu rumah tangga tersebut tinggal bisa dijadikan desa percontohan melek media digital.

Dari hasil penelitian tersebut dapat dilihat bahwa literasi media digital telah menjadi kebutuhan masyarakat. Dalam hal ini kalangan ibu-ibu yang dipilih karena ibu adalah sosok yang banyak mengurusi keluarga dan lebih dekat dengan anak-anaknya. Berdasarkan permasalahan di atas, maka rumusan masalahnya yaitu: 1) bagaimana memberikan pemahaman kepada ibu-ibu tentang pemanfaatan media digital?; 2) bagaimana mendorong ibu-ibu dapat melakukan pendampingan pada remaja untuk memanfaatkan media digital secara bijak? Tujuan dari kegiatan pengabdian kepada masyarakat ini adalah: 1) memberikan edukasi dan sosialisasi pada para ibu-ibu tentang karakteristik media digital yang diakses remaja; 2) memberikan pengetahuan tentang dampak penggunaan media digital dalam perilaku dan perkembangan psikologis remaja; 3) memberikan dorongan kepada ibu-ibu untuk mampu melakukan pendampingan kepada remaja dalam mengatur penggunaan media digital secara cerdas.Manfaat kegiatan pengabdian kepada masyarakat ini meliputi: 1) menambah wawasan bagi ibu-ibu tentang karakteristik, manfaat dan dampak penggunaan media digital; 2) meningkatkan kemampuan/ketrampilan ibu-ibu dalam menggunakan media digital secara cerdas; 3) membangkitkan kesadaran tentang bahaya dampak negatif media digital bagi kehidupan masyarakat pada umumnya; 4) membangkitkan motivasi untuk peduli dan melakukan pendampingan kepada remaja dalam pemanfaatan media digital; 5) mendorong pemerintah desa untuk bersama-sama melakukan gerakan literasi media, terutama bagi para remaja.

\section{Metode}

Kegiatan pengabdian masyarakat ini ditujukan bagi ibu-ibu anggota KKPA Dusun Jodog, khususnya ibu-ibu yang tergabung pada Kelompok Wanita Tani (KWT) RT 04 desa Gilangharjo Kecamatan Pandak Kabupaten Bantul. Kegiatan pendampingan literasi media digital ini diharapkan memberikan manfaat bagi ibu-ibu di Desa Gilangharjo agar mereka dapat 
menggunakan media digital secara bijak dan cerdas. Salah satu kelemahan masyarakat Indonesia dalam penggunaan media digital, kurangnya kemampuan mereka untuk memahami dampak dari penggunaan media tersebut. Masyarakat lebih condong untuk menganggap media gadget sebagai bagian dari media hiburan, sehingga akhirnya tidak ada manfaat yang didapat mereka dari teknologi tersebut.

Ibu-ibu yang menjadi sasaran kegiatan ini terdiri dari ibu-ibu rumah tangga dan ibu pekerja. Mereka cukup aktif dalam kegiatan RT pada khususnya dan kegiatan di Dusun Jodog pada umumnya. Kegiatan ini mampu untuk mendorong para ibu untuk aktif mendiskusikan pendidikan anak-anak mereka. Untuk itu, perlu memberdayakan para ibu tersebut dalam memanfaatkan media digital dalam lingkungan keluarga mereka.

Pendekatan literasi media menurut Postman, Buckingham (Herlina, 2019) ada empat, yaitu:

a. Pendekatan proteksinisme yakni bertujuan untuk melindungi khalayak dari durasi penggunaan media yang berlebihan, konten negatif dan berselera rendah. Khalayak diberi pembekalan untuk membatasi durasi dan konten media yang diakses. Bentuk program misalnya diet media, pengaturan jadwal penggunanan media dan lain-lain

b. Pendekatan Uses and Gratification, pendekatan ini berkebalikan dengan pendekatan di atas, karena menganggap khalayak pandai memilih media sehingga mereka mendapat bekal untuk kemampuan membuat keputusan sendiri. Pendekatan ini menekankan aspek kognitif yang materinya memberikan pengetahuan makro, analisis sosial dan perubahan sosial.

c. Pendekatan khalayak aktif, mirip dengan pendekatan kedua namun alih-alih memberi penekanan kognitif ketrampilan khalayak tetapi lebih mendorong mereka memutuskan sendiri solusi yang tepat untuk mengatasi permasalahan dalam akses media. Literasi media dianggap sebagai cara untuk membentuk opini kritis.

d. Pendekatan Cultural Studies, memandang literasi media merupakan bagian dari program demokratisasi media dan masyarakat secara umum. Khalayak diberi pengetahuan mengenai pengetahuan mikro (konten media) dan makro (lingkungan media).

Dari empat pendekatan di atas, ibu-ibu anggota KKPA lebih memiliki kecenderungan pada pendekatan proteksinisme dan uses and gratification. Kedua pendekatan ini didasari oleh anggapan bahwa mereka perlu dilindungi namun juga memahami bahwa mereka juga memiliki kemampuan dalam memilih media yang tepat dan bermanfaat. Untuk itu, maka metode yang tepat dilaksanakan untuk para ibu anggota KKPA adalah sebagai berikut:

1. Sosialisasi tentang literasi media digital tentang kegiatan yang dilakukan dan mendapatkan masukan tentang pola penggunaan media digital mereka dan anak-anak mereka. Untuk itu kegiatan dilakukan melalui FGD daring.

2. Pemetaan terhadap perilaku dan kebiasaan penggunaan media digital dan bersamasama mencari solusinya. Kegiatan ini dilakukan dengan menggunakan metode FGD daring.

3. Pelatihan dan pendampingan literasi media digital. Kegiatan ini dilakukan secara daring dengan menggunakan metode ceramah dan praktik pendampingan. 


\section{Jcommate

4. Evaluasi dan monitoring dari kegiatan pendampingan literasi media digital. Kegiatan ini dilakukan dengan menggunakan metode FGD daring.

\section{Hasil dan Output}

\section{Deskripsi Ibu-Ibu KKPA di Dusun Jodog}

KKPA memiliki kader atau dalam hal ini disebut satuan tugas (satgas) yang tersebar di seluruh dusun wilayah Desa Gilangharjo. Pada awalnya tiap dusun hanya diwakili oleh dua orang kader saja, namun mulai tahun 2020 ini pada tiap dusun sudah bertambah menjadi empat orang. Walaupun hanya empat orang saja yang terlibat menjadi satgas KKPA, namun keberadaan KKPA di dusun Jodog telah diterima dengan baik dan sudah terinformasikan dengan baik pula, sehingga dapat dikatakan bahwa semua keluarga di Dusun Jodog merupakan sasaran kerja KKPA. Ibu-ibu yang tidak resmi menjadi kader KKPA memiliki kepedulian yang tinggi terhadap permasalahan anak, sehingga mereka sudah terbiasa terlibat dalam kegiatan-kegiatan yang berkaitan dengan permasalahan kesejahteraan dan perlindungan anak.

\section{Rincian Kegiatan}

\section{Pelaksanaan Kegiatan}

Kegiatan ini dilaksanakan sebanyak dua kali dengan menerapkan dua metode, yaitu:

a) Metode ceramah, diskusi, dan tanya jawab.

Kegiatan ini berupa pemberian pemahaman tentang literasi media digital secara umum dan kaitannya dengan perkembangan saat ini terutama pada masa pandemi covid-19 ini, dimana orang tua diperhadapkan pada suatu kebiasaan baru untuk mendampingi anak-anaknya dalam pembelajaran daring. Banyak pengalaman dan persoalan yang dijadikan diskusi bersama. Kesulitan terbesar yang dihadapi ibu-ibu adalah manajemen waktu antara pekerjaan rumah tangga, pekerjaan (bagi ibu bekerja) dan waktu untuk mendampingi anak-anak belajar daring. Banyak ibu-ibu yang masih memiliki keterbatasan akses aplikasi-aplikasi yang digunakan untuk pembelajaran daring. Belum lagi persoalan keterbatasan sarana handphone/smartphone jika di dalam satu rumah terdapat beberapa anak yang harus mengikuti pembelajaran daring, sementara orang tua juga harus mengurusi pekerjaannya.

b) Metode pendampingan

Kegiatan pendampingan ini menghasilkan beberapa hal berikut:

1) Ibu-ibu sangat menyadari bahwa pendampingan kepada anak harus dilakukan dengan memperkuat komunikasi personal antara orang tua dan anak.

2) Kunci sukses dalam penggunaan media digital antara lain: harus menyaring setiap informasi yang diterima, jangan panic, harus bijaksana menyikapi informasi, dan harus memiliki komitmen bersama diantara anggota keluarga dalam mengakses media digital. 
3) Ibu-ibu memiliki pemahaman bersama bahwa anak-anak sejak kecil sudah "dijajah" oleh handphone, sehingga banyak anak-anak menjadi dewasa lebih cepat. Hal ini banyak memunculkan fenomena pernikahan dini.

4) Pembelajaran daring yang dilakukan semenjak pandemi covid-19 memiliki sisi-sisi negatif, diantaranya adalah anak-anak cenderung menurun kedisiplinannya karena mereka belajar tidak sesuai jadwal di sekolah, banyak anak yang menggunakan waktu-waktu belajar untuk bermain HP.

5) Dibutuhkan komunikasi intensif antara orang tua, anak dan pihak sekolah untuk mencari solusi terbaik mengatasi kesulitan keterbatasan alat dalam suatu keluarga. Ada satu keluarga terdiri dari tiga anak yang harus belajar daring namun mereka hanya memiliki satu HP, sehingga ada anak yang dirugikan karena tidak dapat memenuhi tugas-tugas yang diberikan oleh gurunya.

6) Dibutuhkan komitmen bersama diantara anggota masyarakat untuk membantu keluarga-keluarga yang orang tuanya memiliki keterbatasan pengetahuan dan alat dengan cara memfasilitasi anak-anak untuk dapat belajar bersama di suatu tempat yang memiliki akses internet memadai dan jika perlu didampingi oleh para relawan .

7) Permasalahan pembelajaran daring juga diusulkan untuk diatasi bersama pihak sekolah terutama kesulitan anak-anak mengerjakan tugas dari sekolah sementara mereka memiliki keterbatasan faslilitas, yaitu dengan cara anak-anak diperbolehkan menggunakan fasilitas sekolah. Hal ini perlu dikomunikasikan kepada pihak sekolah.

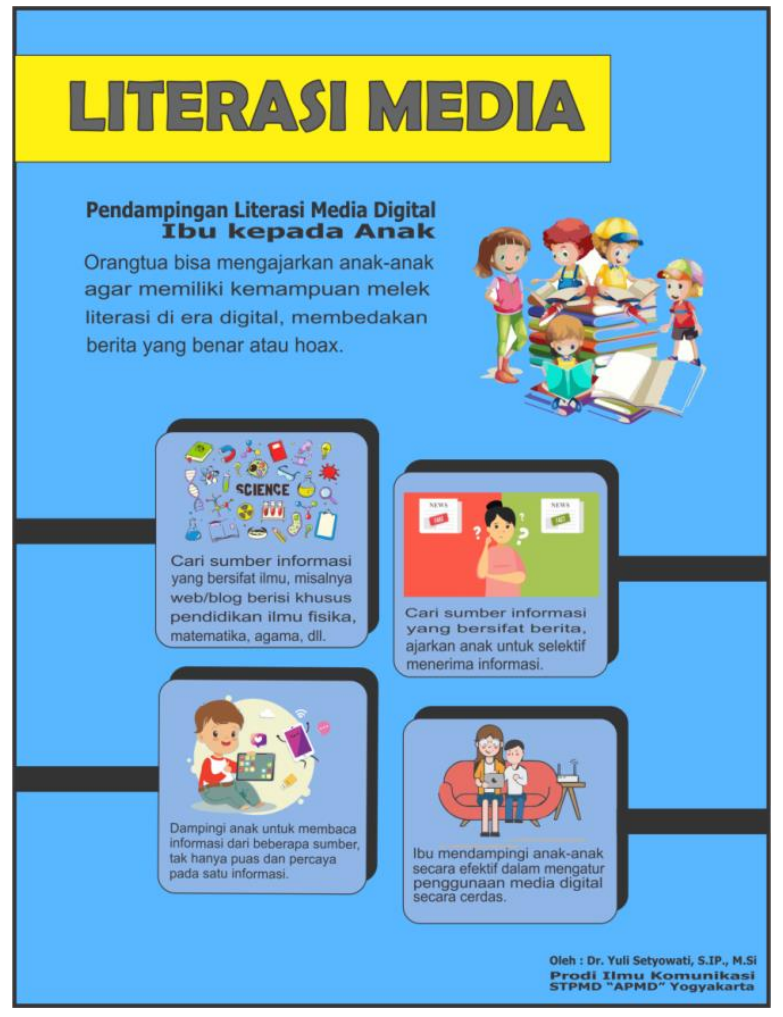

Gambar 1. Poster sebagai output dari kegiatan pengabdian kepada masyarakat ini: 


\section{Jcommde

\section{Materi Kegiatan}

Untuk membekali peserta, materi kegiatan ini disusun dalam bentuk presentasi power point yang dibagikan kepada peserta kegiatan. Materi difokuskan ke dalam dua hal, yaitu: literasi media digitall secara umum dan peran orang tua dalam pendampingan kepada anak-anak dalam hal penggunaan gadget dan pendampingan dalam pembelajaran daring. Ada beberapa langkah agar dapat menjaga anak dengan aman di dunia maya, langkah-langkah tersebut antara lain (www.literasidigital.id): Masuklah ke dunia online mereka; buatlah aturan; ajarkan mereka untuk melindungi privasi; perhatikan lokasi; jadilah sahabatnya; setting mesin pencari; dan kenali situs dan aplikasi yang aman untuk usianya.

\section{Pembahasan}

Media digital marak menjadi perbincangan akhir-akhir ini. Masyarakat dapat secara bebas mengkonsumsi dan memproduksi konten-konten secara luas dalam media digital. Sepintas memang tidak ada masalah karena teknologi semakin berkembang menuntut masyarakat untuk terus mengikutinya aghar tidak ketinggalan jaman. Namun demikian, di balik kemajuan teknologi ini membawa konsekuensi yang luar biasa besar. Perubahan peradaban juga terjadi dengan diciptakannya media baru ini. Dampak negatif banyak ditimbulkan karena penggunaan yang tidak cerdas. Walaupun demikian, terdapat banyak kelebihan yang dimiliki oleh media digital, yaitu: dari segi jangkauan media ini dapat menjangkau seluruh dunia; dari segi kecepatan media ini sangat cepat menyebarkan informasi; kekayaan isinya pun tidak diraguran lagi karena memuat berbagai konten; banyak digunakan untuk kepentingan berkomunikasi; dan relative tidak membutuhkan keahlian khusus untuk mengakses dan memproduksi pesan pada media ini.

Literasi media berasal dari bahasa Inggris yaitu media literacy, terdiri dari dua suku kata media berarti media tempat pertukaran pesan dan literacy berarti melek, kemudian dikenal dalam istilah Literasi Media" (Tamburaka, 2013). "Dalam hal ini literasi media merujuk kemampuan khalayak yang melek terhadap media dan pesan media massa dalam konteks komunikasi massa" (Tamburaka, 2013). Literasi Media dapat dipahami dari pengertian dari Potter yang menyebutkan bahwa media literasi adalah suatu rangkaian perspektif yang kita gunakan secara aktif untuk menerpa diri kita dengan media untuk menginterpretasikan makna dari pesanpesan (media) yang kita temui. Kita membangun perspektif kita dari struktur pengetahuan. Untuk membangun struktur pengetahuan, kita memerlukan peralatan dan materi-materi mentah. Peralatan tersebut adalah keterampilan kita. Sedangkan materi mentah tersebut adalah informasi yang kita dapat dari media dan dari dunia nyata. Penggunaan secara aktif berarti bahwa kita waspada akan pesan-pesan (media) dan dengan sadar berinteraksi dengannya (Potter, 2005).

Definisi literasi media yang ditawarkan oleh New Media Consortium pada tahun 2005 adalah sebagai berikut: "The set of abilities and skills where aural, visual, and digital literacy overlap. These include the ability to understand the power of images and sounds, to recognize and use that power, to manipulate and transform digital media, to distribute them pervasively, and to easily adapt them to new forms" (Jenkins, 2009). Berdasarkan definisi di atas literasi 
media merupakan kemampuan dan keterampilan secara verbal, visual, dan digital saling berkaitan. dimana kekuatan gambar dan suara mampu memanipulasi atau mempengaruhi dan mentransformasi media digital, yang kemudian dapat disebarluaskan dan disesuaikan serta diterima oleh masyarakat luas.

Media digital termasuk salah satu gadget dalam media baru yang didefinisikan oleh menurut McQuail (dalam Ibrahim dan Akhmad, 2014) terdapat empat kategori utama yaitu; 1) media komunikasi interpersonal seperti email, 2) media permainan interaktif seperti game, 3) media pencarian informasi seperti mesin pencarian di Net, 4) media partisipatoris seperti ruang chat di Net. Dalam memanfaatkan media digital terdapat beberapa cara yang mampu merubah cara belajar, bermain dan bermasyarakat, yakni (Tonna Balya, Sri Pratiwi \& Reza Prabudi, 2018): mampu mengidentifikasi akan hak dan tanggungg jawab di ranah online; mampu membedakan antara informasi dan pengetahuan; mampu berpartisipasi di web; mampu membentuk "identitasmu"; dan mampu memahami bahwa privasi merupakan "milikku yang berharga.

Lembaga penyelenggaraan dan pendidikan kini sudah dipengaruhi budaya global, hal ini ditandai dengan kegiatan pembelajaran dalam mencari sumber belajar sudah menggunakan teknologi informasi dan komunikasi, penggunaan teknologi informasi dan komunikasi dijadikan sebagai perangkat dalam mencari, mengolah, mengelola, menampilkan dan menyampaikan sumber belajar. Dikarenakan kebutuhan tersebut maka penyelenggara pendidikan dan pembelajaran akan mengikuti budaya global dengan cara mengimplementasikan perkembangan teknologi informasi dan komunikasi dalam bidang pendidikan dan pembelajaran.

Media digital telah diasumsikan oleh berbagai pihak sebagai perangkat yang membutuhkan teknologi tinggi, orang-orang yang bekerja di dunia pendidikan cenderung memiliki kegemaran untuk selalu melakukan suatu inovasi di dalam lingkungan pembelajarannya. Ketika lembaga penyelenggara pendidikan dan pembelajaran sudah dituntut harus mengimplementasikan pada media digital, hal yang baik adalah lembaga penyelenggara pendidikan dan pembelajaran tidak perlu susah dalam memotivasi siswa untuk menggunakannya, karena secara tidak langsung dengan sendirinya siswa lebih menyenangi pembelajaran menggunakan media digital. Namun tantangan terbesar lembaga penyelenggara pendidikan dan pembelajaran untuk ke depannya adalah cara untuk memotivasi siswa dalam menggunakan media digital secara efektif dan efisien.

Media digital tidak hanya dapat merubah cara siswa mau belajar, tetapi juga akan mengubah cara pendidik dan pengajar dalam berfikir mengenai mengajar dan belajar. Teknologi baru ini akan membentuk budaya baru, dimana media digital penuh dengan potensi kreatif namun pada saat yang sama pula memiliki potensi penyalahgunaan dan bahkan "pelecehan". Kehadiran media digital dalam sebuah lembaga penyelengara pendidikan dan pembelajaran tidak selalu menguntungkan siswa dan meningkatkan mutu pembelajaran, dengan kata lain siswa yang terkena paparan media digital tidaklah cukup apabila tidak dibekali dengan pengetahuan dalam penggunaan media digital dengan bijak sehingga tidak ada jaminan bahwa belajar menggunakan media digital pembelajaran akan dapat berlangsung dengan baik. Penggunaan media digital secara efektif dan efisien merupakan tantangan dan peluang bagi 


\section{Jcommdev}

JCommdev- JOURNAL OF COMMUNITY DEVELOPMENT \& EMPOWERMENT

pendidik dan pengajar, jika efektifitas dan efisiensi tidak dihiraukan oleh pengguna maka hasilnya akan membawa dampak negatif bagi siapapun yang menggunakannya.

Media baru yang marak digunakan saat ini mengalahkan media konvensional menimbulkan dampak bagi penggunanya, terutama bagi anak-anak. Dalam buku The Handbook of Comunication Science, dibahas mengenai Computer Mediated Communication, (Berger, Roloff, Ewoldsen, 2014) yang mengemukakan 6 hal yang akan selalu terkait dan menyertai komunikasi sosial melalui internet, yaitu: 1) berkurangnya komunikasi tatap muka dan cenderung berkurangnya ekspresi non verbal yang memang sudah menjadi ciri dalam interaksi melalui tulisan/text; 2) berhubungan dengan orang-orang yang tidak mengetahui topik atau dengan orang-orang yang memang menjadi bagian dari topik pembahasan; 3) bagaimana penggambaran diri sendiri dan orang lain melalui anonimitas yang absolut, pseudonymity, identifikasi nominal atau usaha untuk mengautentifikasi kualifikasi orang lain; 4) waktu berbalas pesan yang tidak sinkron; 5) khalayak potensial yang dapat dijangkau jauh lebih besar dibandingkan dengan jumlah individu dalam komunikasi tradisional; 6) mampu menjawab pesan secara 'bersembunyi' tanpa mengacaukan pesan.

Byron Reeves dan Clifford Nass mengemukakan The Media Equation Theory atau Teori Persamaan Media (Griffin, 2003), bahwa media diibaratkan manusia, media juga bisa diajak berbicara. Media bisa menjadi lawan bicara individu seperti dalam komunikasi interpersonal yang melibatkan dua orang dalam situasi face to face adalah benar adanya. Ibu-ibu Dusun Jodog mengakui bahwa mereka sangat tergantung dengan media digital. Disamping berfungsi positif seperti bisa digunakan sebagai alat bertukar informasi, sebagai media untuk mengundang acara-acara tertentu, untuk berjualan secara online, mendapatkan informasiinformasi, tetapi mereka juga menyadari bahwa media ini banyak berdampak negatif. Banyak penipuan dilakukan melalui media online, berita hoax, pornografi, dan sebagainya. Dari segi waktu pun banyak tersita hanya untuk melihat aplikasi dan konten-konten yang menarik di media digital. Oleh sebab itu, literasi media digital pertama harus dipahamkan kepada ibu-ibu sebagai pendamping anak-anaknya, agar mereka mampu mendampingi anak-anaknya secara lebih efektif.

\section{Simpulan dan Saran}

Kegiatan pendampingan literasi media digital untuk pendampingan anak bagi ibu-lbu anggota KKPA di Dusun Jodog sengaja memilih ibu-ibu sebagai fokusnya karena ibu-ibu merupakan pilar rumah tangga dalam keluarga. Apabila pilar ini kuat, maka rumah tangga tersebut akan kokoh. Benteng pertama bagi generasi penerus adalah keluarga, untuk itu ibu-ibu rumah tangga perlu dibekali pendidikan literasi media.

Kegiatan pendampingan ini menghasilkan beberapa hal berikut: 1) Ibu-ibu semakin paham tentang karakteristik, manfaat, cara penggunaan, dan dampak yang ditimbulkan oleh media digital, walaupun mereka masih banyak menghadapi persoalan dengan dampak penggunaan media digital tersebut; 2) Ibu-ibu semakin paham tentang dampak penggunaan media digital dalam perilaku dan perkembangan psikologis anak-anak untuk memininalkan dampak negatif media digital. Hal ini sangat berkaitan erat dengan visi misi KKPA dalam 
menciptakan kesejahteraan dan perlindungan anak, dalam hal ini perlindungan anak dari pengaruh negatif media digital; 3) lbu-ibu semakin efektif melakukan pendampingan kepada anak-anak dalam mengatur penggunaan media digital secara cerdas, terutama pada masa pandemi covid-19 dengan cara melakukan pendampingan pembelajaran daring kepada anakanak secara lebih efektif dan bijaksana.

Dibutuhkan komitmen bersama di dalam keluarga tentang penggunaan media digital agar terhindar dari dampak negatif. Dalam hal ini orang tua perlu menjadi teladan bagi anakanaknya. Dibutuhkan pula komunikasi intensif antara orang tua, anak dan pihak sekolah untuk mencari solusi terbaik mengatasi kesulitan pembelajaran daring. Serta, dibutuhkan komitmen bersama diantara anggota masyarakat untuk membantu keluarga-keluarga yang orang tuanya memiliki keterbatasan pengetahuan dan alat dengan cara memfasilitasi anak-anak untuk dapat belajar bersama.

\section{Daftar Pustaka}

Berger, Charles R, Roloff, Michael E., dan Ewoldsen, David R.Roskos. 2014. Handbook Ilmu Komunikasi. Bandung: Penerbit Nusa Media.

Griffin, Em. 2003. A First Look at Communication Theory. New York: McGraw-Hill

Herlina, Dyna. 2019. Literasi Media Teori dan Aplikasi. Bandung: Rosda Karya

Ibrahim, Idi Subandy dan Bachruddin Ali Akhmad. 2014. Komunikasi dan Komodifikasi. Jakarta: Yayasan Pustaka Obor Indonesia

Jenkins, H. (2009). Confronting The Challenges of Participatory Culture: Media Education for the 21st Century. Illinois: MacArthur Foundation.

Dewi Novianti dan Siti Fatonah. 2018. Literasi Media Difital di Lingkungan Ibu-ibu Rumah Tangga di Yogyakarta. Jurnal Ilmu Komunikasi, Volume 16, Nomor 1, Januari - April 2018: 1-14

Potter, W.J. (2001). Media Literacy. California: Sage. Thousand Oaks. Seni dan sejarah Jakarta: Divisi Buku Perguruan Tinggi. Jakarta: Raja Grafindo Persada

Tamburaka, A. (2013). Literasi Media: Cerdas Bermedia Khalayak Media Massa. Jakarta: Raja Grafindo Persada.

Tonna Balya, Sri Pratiwi \& Reza Prabudi. 2018. Literasi Media Digital Pada Penggunaan Gadget, Jurnal Simbolika: Research and Learning in Communication Study, 4 (2) Oktober 2018: 173-187 